\title{
Design, synthesis, nuclear localization, and biological activity of a fluorescent duocarmycin analog, HxTfA
}

Kostantinos Kiakos, ${ }^{\mathrm{a}, \mathrm{b}, *}$, Bernhard Englinger, ${ }^{\mathrm{f}}$ Stephanie K. Yanow, ${ }^{\mathrm{c}}$ Debora Wernitznig, ${ }^{\mathrm{b}}$ Michael A. Jakupec, ${ }^{b}$ Walter Berger, ${ }^{b, f}$ Bernhard K. Keppler, ${ }^{b}$ John A. Hartley, ${ }^{a}$ Moses Lee, ${ }^{d, e}$ Pravin C. Patil ${ }^{d}$

${ }^{a}$ Cancer Research UK Drug-DNA Interactions Research Group, UCL Cancer Institute, London WC1E 6BT, United Kingdom

${ }^{b}$ Institute of Inorganic Chemistry, University of Vienna, Waehringer Str. 42, 1090 Vienna,

Austria; Research Cluster "Translational Cancer Therapy Research", University of Vienna, Waehringer Str. 42, 1090 Vienna, Austria

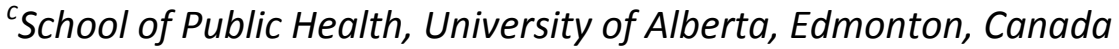

${ }^{d}$ Department of Chemistry, Hope College, Holland, MI 49423, United States

${ }^{e}$ Present address: Department of Chemistry, Georgia State University, Atlanta, GA 30303, United

States

Institute of Cancer Research and Comprehensive Cancer Center, Department of Medicine I, Medical University of Vienna, Borschkegasse 8a, A-1090 Vienna, Austria

*Corresponding author's present address: Institute of Inorganic Chemistry, University of Vienna, Waehringer Str. 42, 1090 Vienna, Austria. Tel.: +431427752610; fax: +43142779526 Email address: konstantinos.kiakos@univie.ac.at

\begin{abstract}
:
HxTfA 4 is a fluorescent analog of a potent cytotoxic and antimalarial agent, TfA 3, which is currently being investigated for the development of an antimalarial vaccine, PlasProtect ${ }^{\circledR}$. HxTfA contains a p-anisylbenzimidazole or $\mathrm{Hx}$ moiety, which is endowed with a blue emission upon excitation at $318 \mathrm{~nm}$; thus enabling it to be used as a surrogate for probing the cellular fate of TfA using confocal microscopy, and addressing the question of nuclear localization. HxTfA exhibits similar selectivity to TfA for A-tract sequences of DNA, alkylating adenine-N3, albeit at 10-fold higher concentrations. It also possesses in vitro cytotoxicity against A549 human lung carcinoma cells and Plasmodium falciparum. Confocal microscopy studies showed for the first time that HxTfA, and by inference TfA, entered A549 cells and localized in the nucleus to exert its biological activity. At biologically relevant concentrations, HxTfA elicits DNA damage response as evidenced by a marked increase in the levels of $\gamma \mathrm{H} 2 \mathrm{AX}$ observed by confocal microscopy and immunoblotting studies, and ultimately induces apoptosis.
\end{abstract}

Keywords: Duocarmycins, tafuramycin A, cytotoxic, antimalarial, vaccine, minor groove, adenine-N3, alkylating agent

Duocarmycin SA 1 (Figure 1), ${ }^{1}$ yatakemycin, ${ }^{2}$ and CC $-1065^{3}$ are the parent members of a potent class of antitumor natural products that contain two components: the cyclopyrroloindolone 
(CPI) DNA alkylating moiety and a non-covalently active portion, such as the 5,6,7trimethoxyindole (TMI). The crescent-shaped molecules fit snugly in the minor groove of ATrich sequences of DNA. Upon binding, the reactivity of the cyclopropane moiety, as in $\mathbf{1}$, is enhanced for covalent bonding with adenine-N3, ${ }^{4}$ leading to the killing of cancer cells through apoptosis. ${ }^{5}$ Due to clinical toxicity observed with the initial group of CC-1065 and duocarmycin analogs, such as adozelesin, bizelesin, carzelesin, and KW2189, a major effort has been underway for over two decades to develop analogs that are more targeted, more selectively active, and less systemically toxic. ${ }^{6}$ As a result, numerous duocarmycin analogs have been developed. Examples include: seco-cyclopropylbenzoindoline-TMI (2, Figure 1), a stable, sequence specific, and highly cytotoxic agent; ${ }^{7}$ centanamycin, (achiral seco-amino-CBI-TMI), ${ }^{8}$ an orally active anticancer agent against human cancer xenografs; ${ }^{9}$ and seco-isocyclopropylfuranoindoline-trimethoxyindole (seco-iso-CFI-TMI or tafuramycin A or TfA 3), ${ }^{10}$ a potent cytotoxic agent against cancer cells. Recently, both centanamyin ${ }^{11}$ and $\operatorname{TfA}^{12}$ were reported to exhibit potent cytotoxic activity against Plasmodium falciparum. Seco-compounds, such as $\mathbf{2}$ and 3, Figure 1, eliminate $\mathrm{HCl}$ in cells to form the ultimate cyclopropane drugs, e.g., 3a, which bind and covalently bond with adenine-N3 on DNA. TfA is a critical component in the development of the antimalarial vaccine, PlasProtec ${ }^{\circledR}$, which is currently being tested clinically. ${ }^{12}$ Another duocarmycin analog, DUBA, is currently undergoing clinical evaluation and is part of a HER2-targeting antibody-drug conjugate SYD985, which is being developed clinically for HER2-expressing breast cancers. ${ }^{13}$
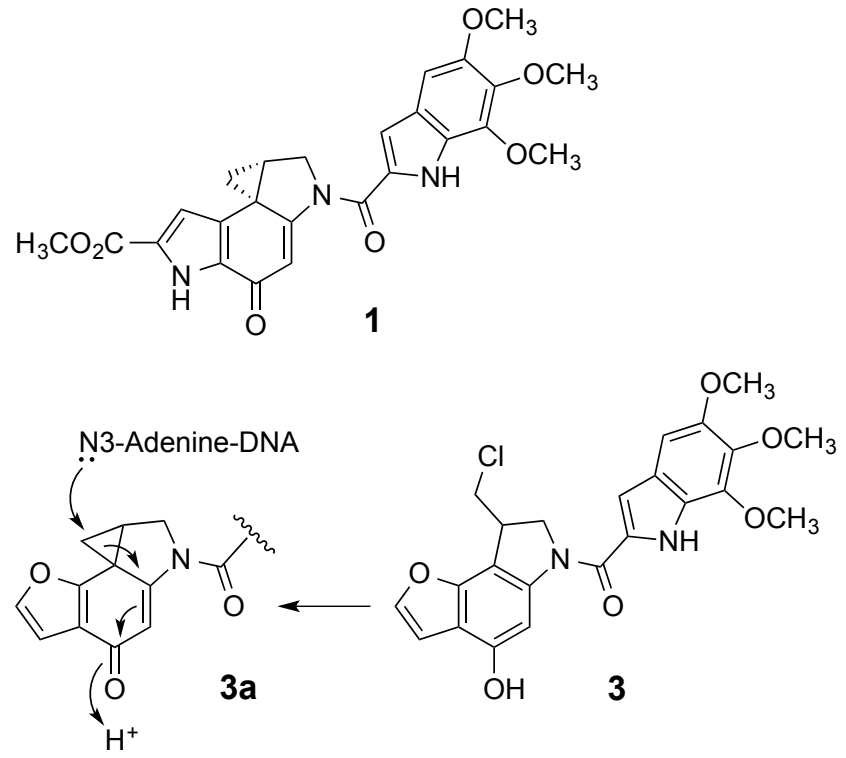
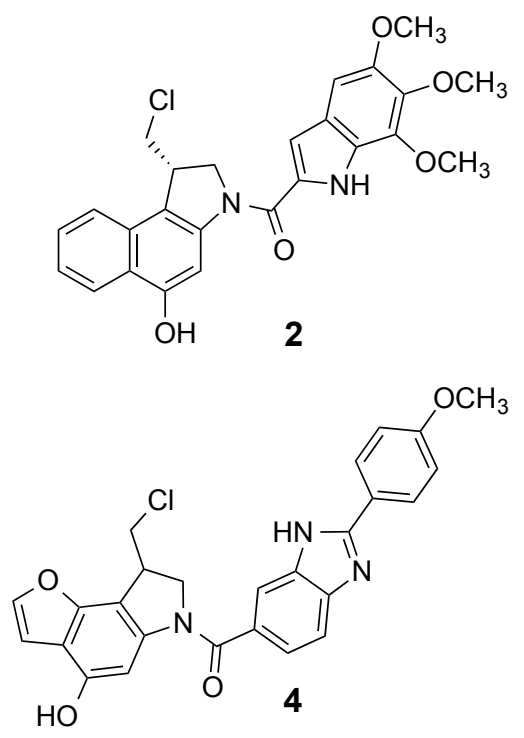

Figure 1

Despite the major progress made so far in the duocarmycins and CC-1065 field for the development of novel anticancer and antiparasitic agents, one important question that needs to be answered is evidence of nuclear localization of these compounds. Since duocarmycins 
have been shown to bind and alkylate naked and genomic DNA extracted from cells, ${ }^{1,8 b, 14}$ it is often assumed that these compounds interact with nuclear DNA. Recently, Tietze's group reported the design and synthesis of a number of coumarin-based, fluorescent duocarmycin analogs for the purpose of studying the molecular fate of the compounds in live cancer cells using confocal microscopy. ${ }^{15}$ Even though the compounds displayed strong cytotoxicity against the growth of cancer cells, surprisingly, they penetrated the cellular membrane and accumulated in the mitochondria, inducing apoptosis. Another effort led by Tercel's group involved the development of terminal-alkyne-containing duocarmycin analogs; upon binding to DNA, the alkyne moiety could be "clicked" with a reporter fluorophone-azide to determine nucleus localization. ${ }^{16}$ The authors cautioned that "care must be exercised in interpreting sites of intracellular probe molecule localization on the basis of a click fluorescent read-out, especially where multiple diverse targets are possible, and even more so when some of these targets may be within the nucleus." ${ }^{16}$ Since our group has been actively developing inherently fluorescent, DNA sequence selective, $\mathrm{Hx}$-containing pyrrole-imidazole polyamides, or $\mathrm{Hx}$ amides, ${ }^{17}$ we envisioned that the $\mathrm{Hx}$-moiety would be an appropriate replacement of the TMI unit in duocarmycins. Hx would retain the AT sequence and minor groove selectivity, and provide an anchor needed to "twist" and activate the cyclopropane toward nucleophilic reaction with adenine-N3. It would also come with the added benefit of the inherent fluorescent property afforded by the Hx moiety. Accordingly, we report herein the synthesis of seco-iso-CFI-Hx or HxTfA 4 as a fluorescent surrogate of TfA 3.

The synthesis of HxTfA is illustrated in Figure 2. Acid catalyzed removal of the BOC protecting group of O-benzylated iso-CFI compound $\mathbf{5}^{18}$ provided an indoline intermediate, which was coupled to $\mathrm{Hx}$-acid $\mathbf{6}^{19}$ in the presence of $\mathrm{EDCl}$. The resulting amide $\mathbf{7}$ was isolated as a white solid in 59\% yield after silica gel column chromatography. Hydrogenolysis of amide $\mathbf{7}$ with $10 \%$ $\mathrm{Pd}$ on carbon at room temperature and atmospheric pressure generated HxTfA in $33 \%$ yield as a white solid after purification by silica gel column chromatograpy. ${ }^{20} \mathrm{~A} 12.5 \mu \mathrm{M}$ solution of HxTfA in 1:1 water:DMSO gave an absorbance at about $320 \mathrm{~nm}$, and excitation at $318 \mathrm{~nm}$ produced a blue emission at $370 \mathrm{~nm}$.

The in vitro cytotoxicity of HxTFA and TFA, against A549 human lung carcinoma cells ${ }^{8,17 c}$ and Plasmodium falciparum ${ }^{11 a, 21}$ was determined following published procedures. The $\mathrm{IC}_{50}$ values (concentrations required to inhibit the growth of cells by 50 percent) of HxTfA and TfA following a 4-day continuous exposure for A549, and a $48 \mathrm{~h}$ exposure for Plasmodium falciparum 3D7 infected red blood cells, were $26 \mathrm{nM}$ and $3.7 \mathrm{nM}$, and $3.7 \mathrm{nM}$ and $64 \mathrm{pM}$, respectively. The results established that HxTfA was about 7-fold less cytotoxic than TfA in A549 cells, and about 60 -fold less active than TfA against Plasmodium. Although the reasons for the difference in cytotoxicities are unknown, one possible explanation is the 10-fold lower DNA reactivity of HxTfA compared to TfA. Interestingly, TfA is generally more cytotoxic against A549 cells than murine cancer cells: $\mathrm{L} 1210$ (lymphoma, $\mathrm{IC}_{50}=53 \mathrm{nM}$ ) and $\mathrm{B} 16$ (melanoma, $\mathrm{IC}_{50}=40 \mathrm{nM}$ ) as reported earlier. ${ }^{10}$ With regard to antimalarial activity, TfA, with an IC 50 value of $64 \mathrm{pM}$, is one of the most potent cytotoxic agents against Plasmodium falciparum (about 30 times more potent than centanamycin), ${ }^{11,22}$ and comprises a critical ingredient for creating the chemically 
attenuated blood-stage parasite-based vaccine, PlasProtect ${ }^{\circledast}$, for targeting human Plasmodium species. $^{12}$

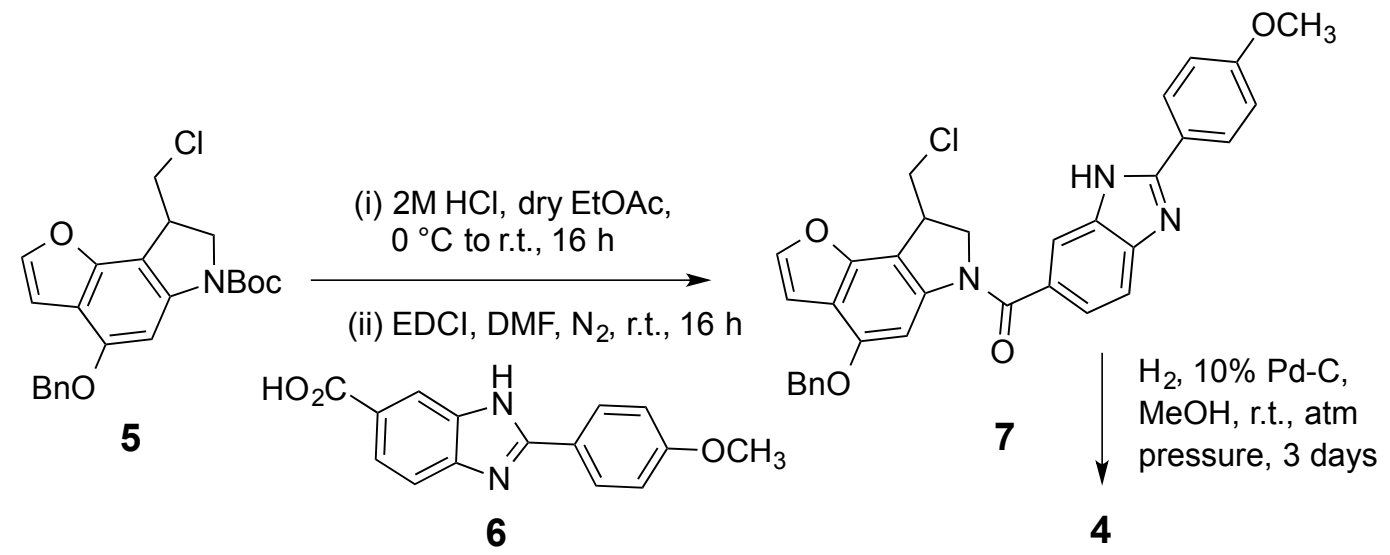

Figure 2

The DNA binding properties of HxTfA and TfA were ascertained using the thermal cleavage assay. ${ }^{8,10 a, b}$ The 749-956 region of the pUC18 plasmid used to probe the purine-N3 alkylations, containing the prominent sites of damage on the bottom strand, was PCR amplified, using the synthetic primer 5'-CTCACTCAAAGGCGGTAATAC-3', and the radiolabelled 5'-

TGGTATCTTTATAGTCCTGTCG-3'. The resulting singly end-labeled fragment was generated, purified, and incubated with HxTfA and TfA for $5 \mathrm{~h}$. The precipitated pellets from the drug-DNA incubations were re-suspended in sodium citrate buffer $\left(\mathrm{pH} \mathrm{7.2)}\right.$ and heated at $90{ }^{\circ} \mathrm{C}$ for $30 \mathrm{~min}$, to thermally cleave at the sites of adenine- or guanine-N3 lesions. ${ }^{8,10 a, b}$ As shown in Figure 3 , both compounds share similar DNA sequence selectivity by covalently interacting with the same cluster of adenines as their predominant site of DNA interaction, alkylating the N3 position of 5'-AAAAA-3' (865), while a secondary cleavage product is also evident at the AT-mixed sequence 5'-TTTTA-3' (843) for HxTfA. TfA appears therefore to be more DNA sequence selective and about 10-fold more reactive with DNA, than HxTfA, as judged by the appearance of the cleavage band at the major alkylation site $\underline{\mathbf{A}}(865)$ at $0.1 \mu \mathrm{M}$, compared to $1 \mu \mathrm{M}$ for HxTfA, which could also explain the higher cytotoxicity of TfA over HxTfA. 


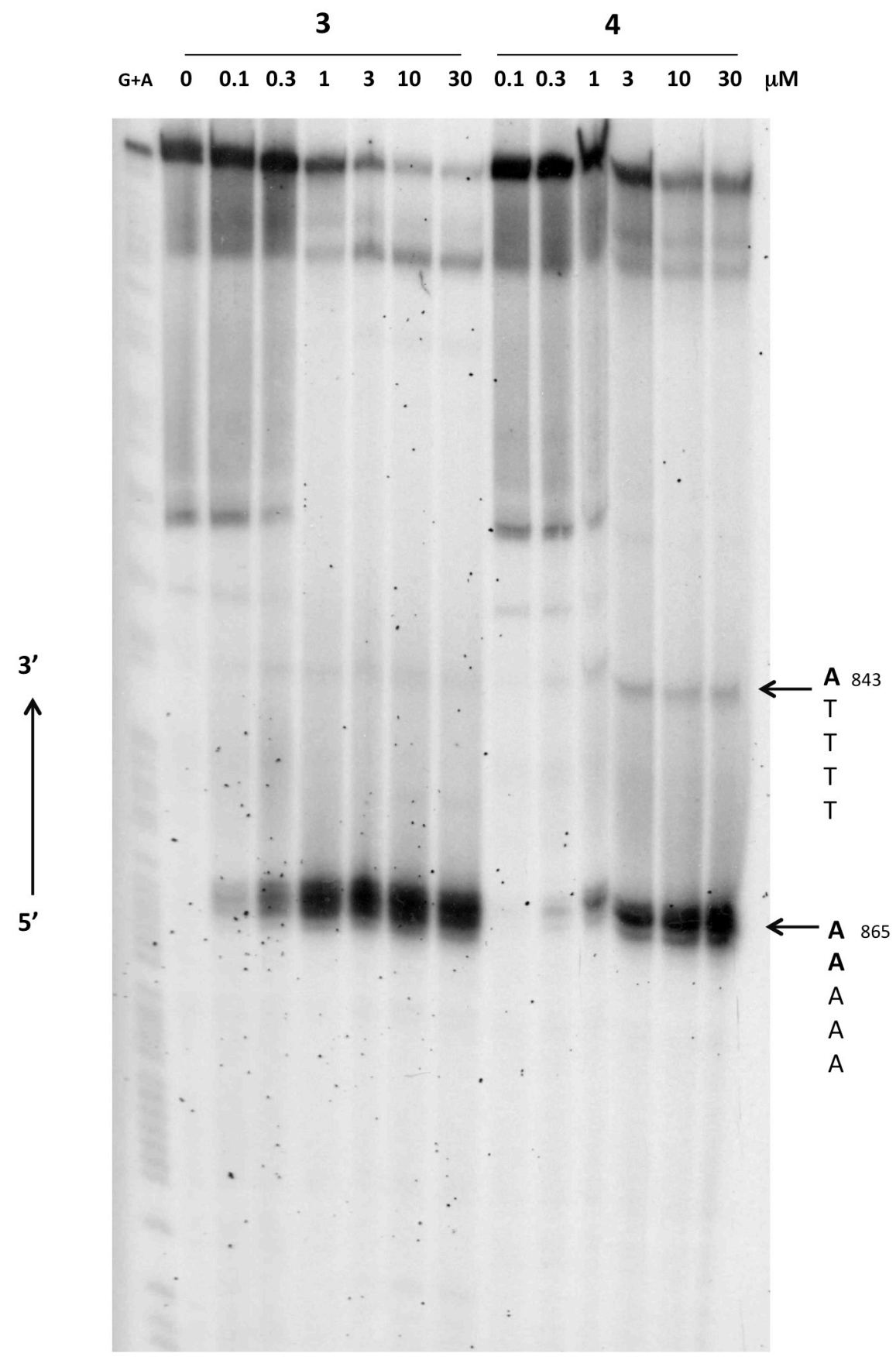

Figure 3

Exploiting the fluorescent properties of HxTfA 4, and following published procedures, ${ }^{17}$ confocal microscopy studies were conducted to determine the compound's cellular uptake. A549 cells were treated with increasing concentrations of $\operatorname{HxTfA}(0,0.5,1.0$, and $5.0 \mu \mathrm{M})$ for $24 \mathrm{~h}$ and representative confocal microscopy images are shown in Figure 4A. Nuclear accumulation was confirmed by co-localization of the HxTfA fluorescence signal (blue) and the propidium iodide (PI) signal (red). HxTfA nuclear staining was evident at $1.0 \mu \mathrm{M}$, thus providing unambiguous 
evidence that HxTfA localizes in the nucleus. Fluorescence microscopy experiments in nonfixed, non-permeabilised A549 cells, treated with HxTfA for $24 \mathrm{~h}$ and counterstained with Mitrotracker ${ }^{\circledR}$ Red CMXRos, further corroborated the HxTfA nuclear uptake (Figure 4B).

A)

PI
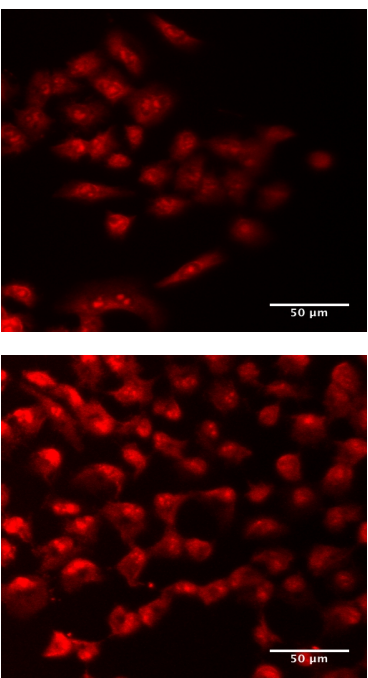

$0.5 \mu \mathrm{M}$

$1.0 \mu \mathrm{M}$

$5.0 \mu \mathrm{M}$

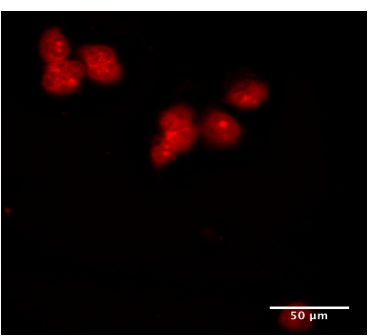

4
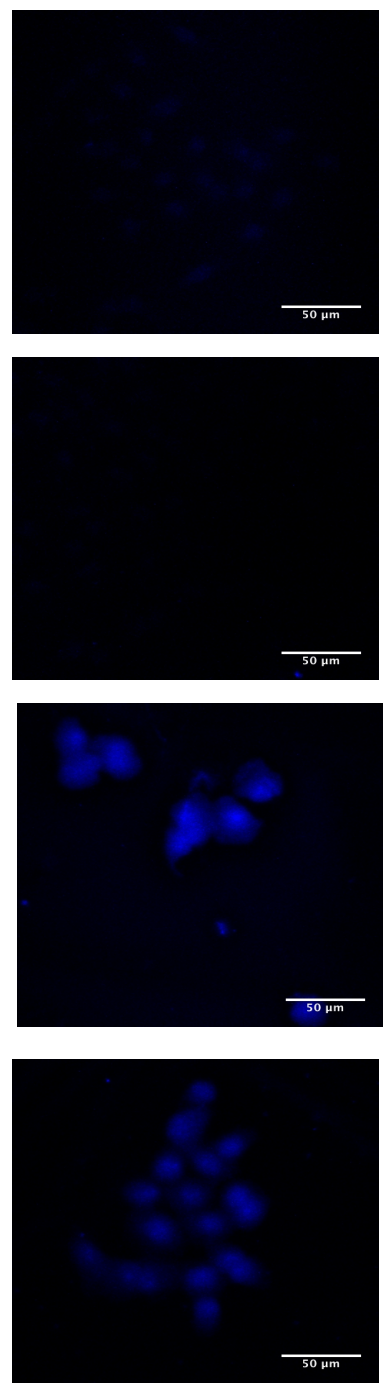

Composite
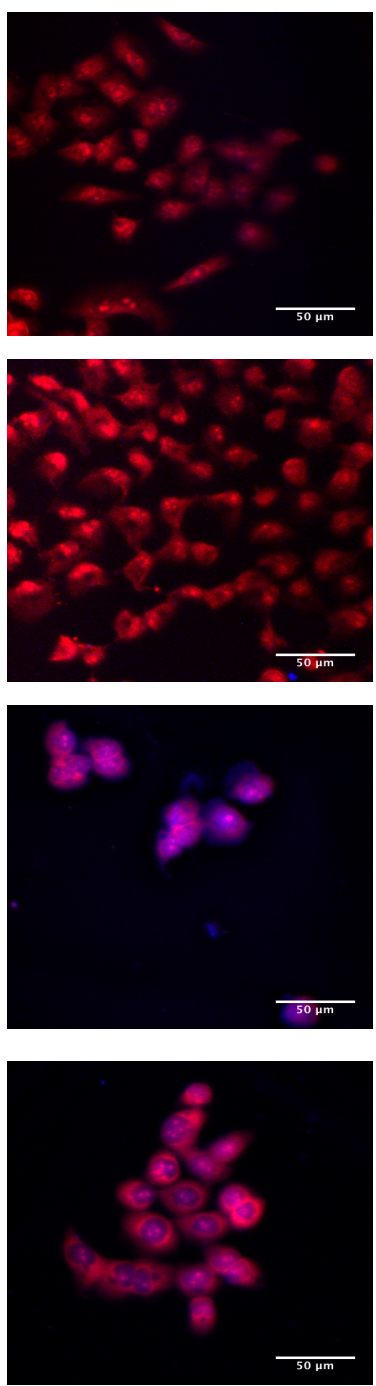
B)
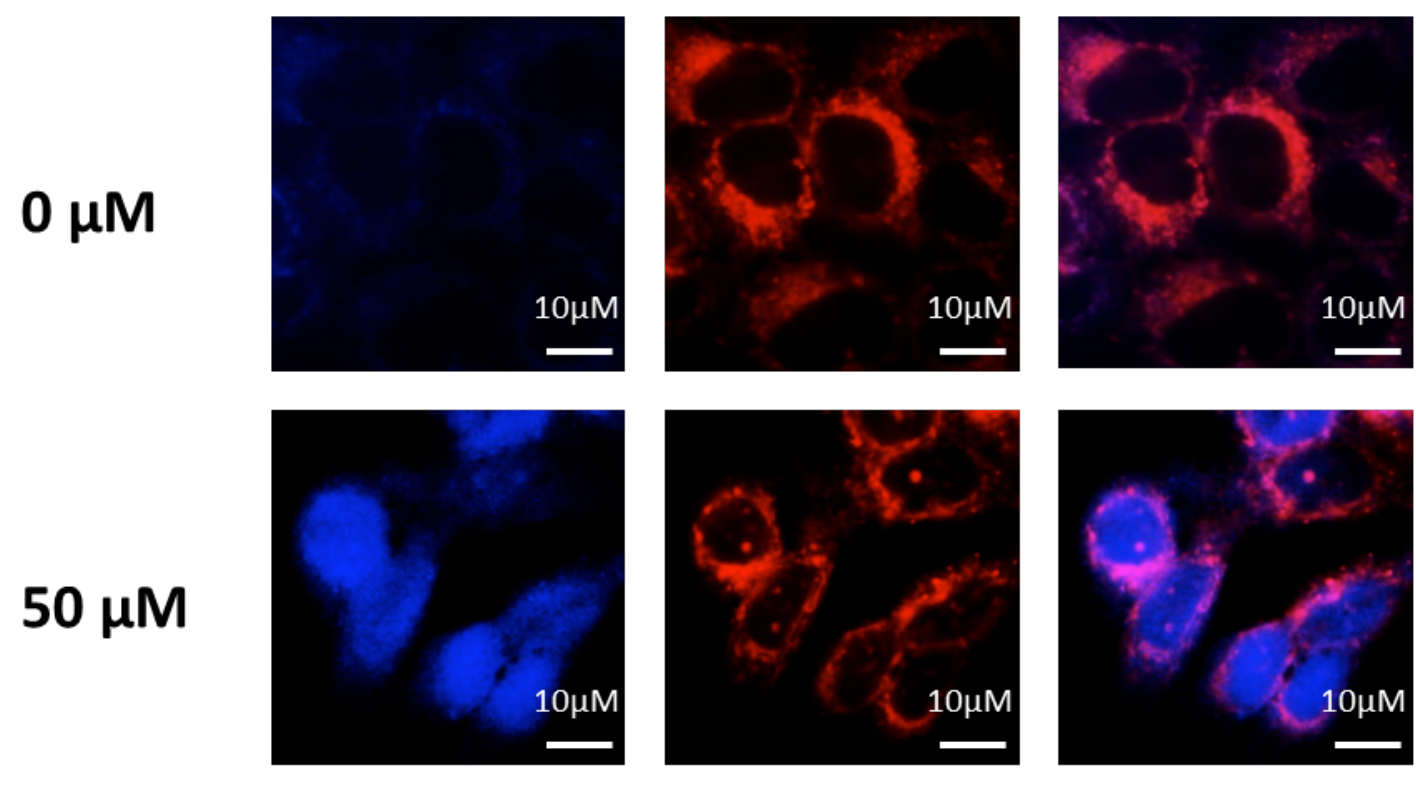

$0 \mu \mathrm{M}$
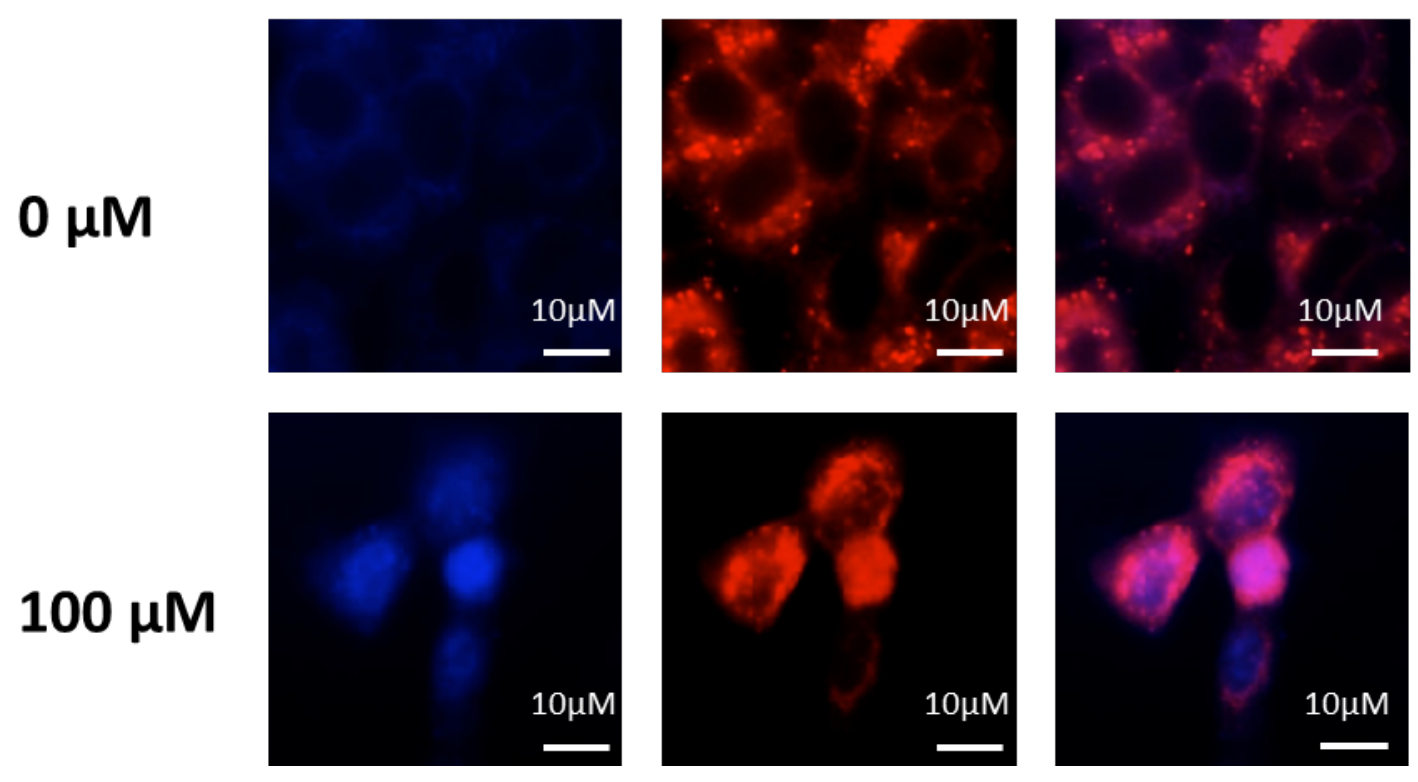

Figure 4

Finally, to ascertain the mechanism of cytotoxicity of HxTfA, immunoblotting experiments (Figure 5A) revealed that exposure of A549 cells to HxTfA (0.1-20 $\mu \mathrm{M})$ for $5 \mathrm{~h}$ followed by $24 \mathrm{~h}$ of recovery caused a marked decrease in the levels of survivin (an anti-apoptotic protein) at concentrations $1 \mu \mathrm{M}$ and higher. Consistent with our previous observations, TfA produced the same effect at a 10 -fold lower concentration $(0.1 \mu \mathrm{M})$. Bcl-xL levels remained largely unaffected. Apoptosis was confirmed by the immunodetection of cleaved caspase-3, upon treatment with 1.0 $\mu \mathrm{M}$ HxTFA (Figure 5B). Furthermore, increased levels of $\gamma-\mathrm{H} 2 \mathrm{AX}$, a 
biomarker for DNA damage response was evident at $0.1 \mu \mathrm{M}$ and became more pronounced at higher drug concentrations. The induction of $\gamma-\mathrm{H} 2 \mathrm{AX}$ was also detected by immunofluorescence, in cells treated with both TfA and HxTfA for $5 \mathrm{~h}$ and allowed to recover in drug-free medium for a further $24 \mathrm{~h}$. Indicative confocal microscopy images shown in Figure 5C revealed that both TfA and HxTfA produce significant nuclear $\gamma-\mathrm{H} 2 \mathrm{AX}$ staining, relative to the untreated cells, with a lower TfA concentration required, consistent with its higher DNA reactivity and cytotoxicity, over HxTfA.

A)

4

3

$\begin{array}{lllllllll}0 & 0.1 & 1 & 5 & 10 & 15 & 20 & \mu \mathrm{M}\end{array}$

$\begin{array}{lllllllll}0 & .05 & 0.1 & 1 & 5 & 10 & 15 & 20 \mu \mathrm{M}\end{array}$

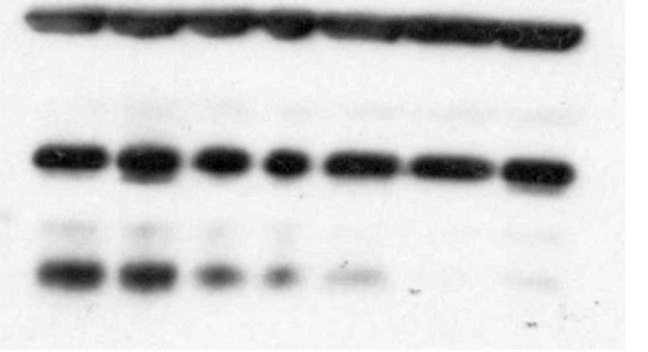

$\beta$-actin

Bcl-xL

survivin

B) 4

$\begin{array}{llllll}0 & 0.1 & 1.0 & 5 & 10 & \mu \mathrm{M}\end{array}$

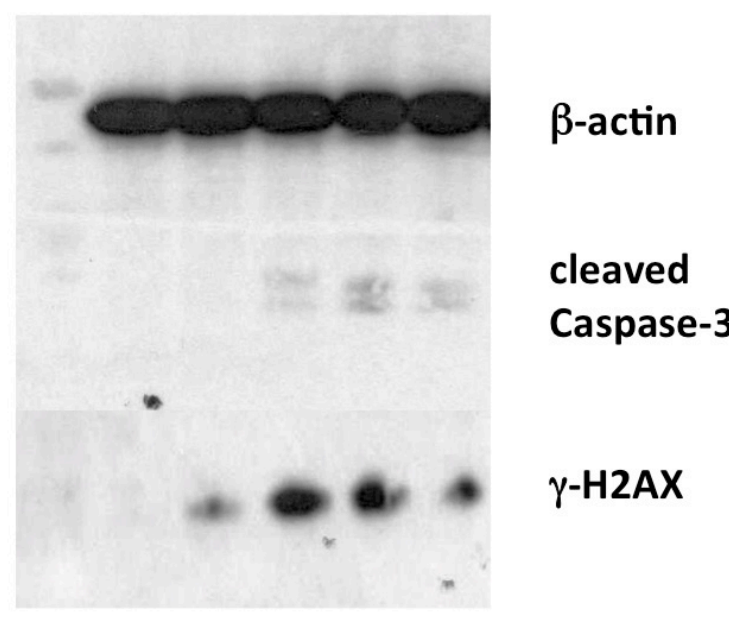


C)

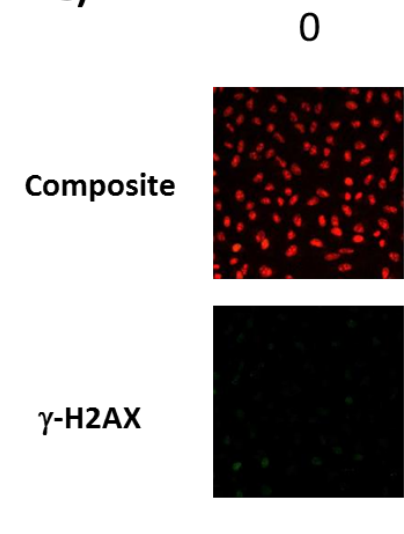

0

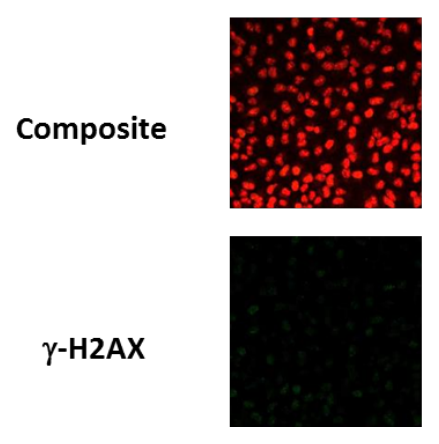

0.1
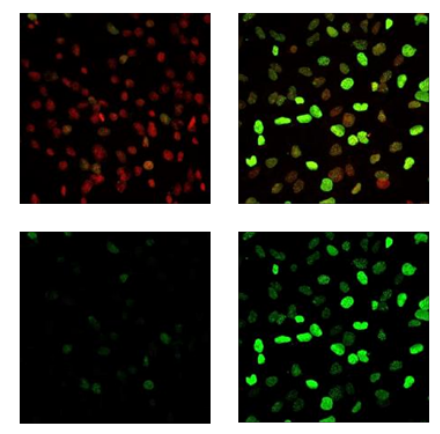

0.5

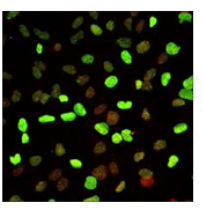

4
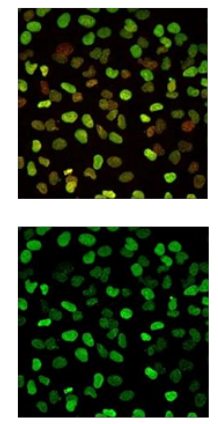

3

0.1
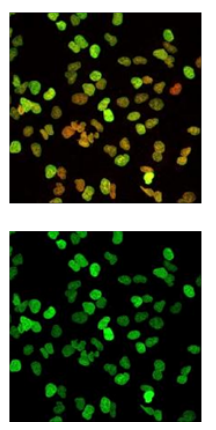

0.5
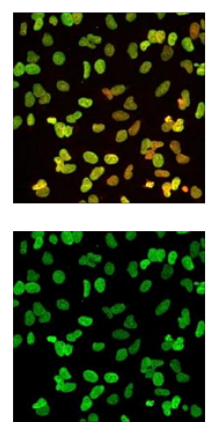

\section{1}
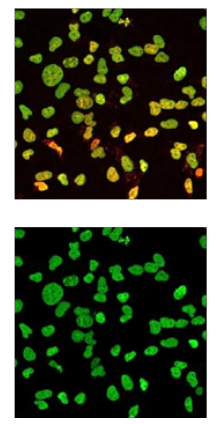

2
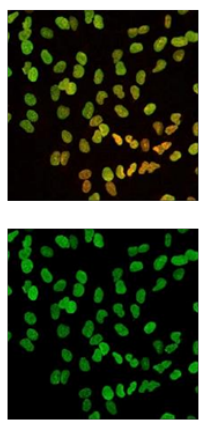

5
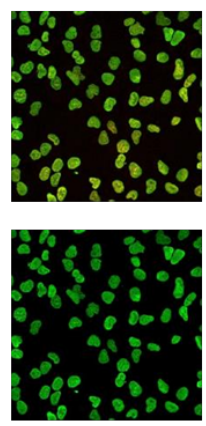

$\mu \mathrm{M}$

2
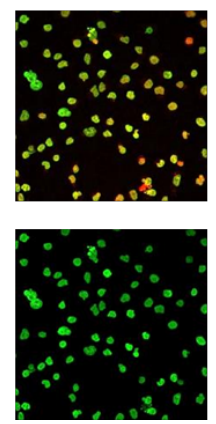

5

$\mu \mathrm{M}$
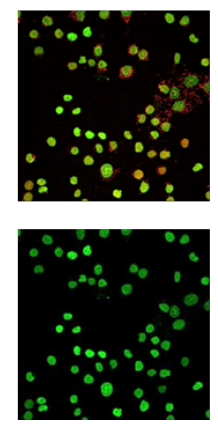

Figure 5

In summary, HxTfA has been shown to readily enter cells, localize in the nucleus, affect cellular processes, and induce apoptosis. Its biological profile is consistent and similar to that of TfA or tafuramycin A, a valuable duocarmycin analog for the development of an antimalarial vaccine. The results support the notion that HxTfA can act as an appropriate surrogate for TfA, for cell studies.

\section{Acknowledgements}

The authors thank the NSF (CHE 0809162) and Cancer Research UK (C2259/A16569). The research leading to these results has received funding from the Mahlke-Obermann Stiftung and the European Union's Seventh Framework Programme for research, technological development and demonstration under grant agreement no. 609431.

\section{References and notes}

1. (a) Boger, D. L.; Johnson, D. S. Angew. Chem. Int. Ed. Engl. 1996, 35, 1438; (b) Boger, D. L. Acc. Chem. Res. 1995, 28, 20; (c) Boger, D. L.; Johnson, D. S. Proc. Natl. Acad. Sci. U.S.A. 
1995, 92, 3642; (d) Boger, D. L.; Garbaccio, R. M. Acc. Chem. Res. 1999, 32, 1043; (e) Tichenor, M. S.; Boger, D. L. Natural Prod. Rep. 2008, 25, 220; (f) Ghosh, N.; Sheldrake, H. M.; Searcey, M.; Pors, K. Curr. Top. Med. Chem. 2009, 9, 1494.

2. Ichimura, M.; Ogawa, T.; Takahashi, K.; Kobayashi, E.; Kawamoto, I.; Yasuzawa, T.; Takahashi, I.; Nakano, H. J. Antibiot. 1990, 43, 1037.

3. (a) Igarashi, Y.; Futamata, K.; Fujita, T.; Sekine, A.; Senda, H.; Naoki, H.; Furumai, T. J. Antibiot. 2003, 56, 107; Structure revision (b) Tichenor, M. S.; Kastrinsky, D. B.; Boger, D. L. J. Am. Chem. Soc. 2004, 126, 8396.

4. Martin, D. G.; Biles, C.; Gerpheide, S. A.; Hanka, L. J.; Krueger, W. C.; McGovren, J. P.; Mizsak, S. A.; Neil, G. L.; Stewart, J. C.; Visser, J. J. Antibiot. 1981, 34, 1119.

5. (a) Wrasidlo, W.; Johnson, D. S.; Boger, D. L. Bioorg. Med. Chem. Lett. 1994, 4, 631; (b) Wang, Y.; Yuan, H.; Ye, W.; Wright, S. C.; Wang, H.; Larrick, J. W. J. Med. Chem. 2000, 43, 1541.

6. Patil, P.C.; Satam, V; Lee, M. Anticancer Agents Med. Chem. 2015, 15, 616.

7. (a) Boger, D. L.; McKie, J. A. J. Org. Chem. 1995, 60, 1271.; (b) Boger, D. L.; Yun, W.; Han, N. Bioorg. Med. Chem. 1995, 3, 1429.

8. (a) Sato. A.; McNulty, L.; Cox, K.; Kim, S.; Scott, A.; Daniell, K.; Summerville, K.; Price, C.; Hudson, S.; Kiakos, K.; Hartley, J. A.; Asao, T.; Lee, M. J. Med. Chem. 2005, 48, 3903. (b) Kiakos, K.; Sato, A.; Asao, T.; McHugh, P. J.; Lee, M.; Hartley, J. A. Mol. Cancer Ther. 2007, 6, 2708.

9. Rayburn, E.; Wang, W.; Li, M.; Zhang, X.; Xu, H.; Li, H.; Qin, J. J.; Jia, L.; Covey, J.; Lee, M.; Zhang, R. Cancer Chemother. Pharmacol. 2012, 69, 1423.

10. (a) Howard, T. T.; Lingerfelt, B. M.; Purnell, B. L.; Scott, A. E.; Price, C. A.; Townes, H. M.; McNulty, L.; Handl, H. L.; Summerville, K.; Hudson, S. J.; Bowen, J. P.; Kiakos, K.; Hartley, J. A.; Lee, M. Bioorg. Med. Chem. 2002, 10, 2941; (b) Purnell, B.; Lingerfelt, B.; Scott, A.; Townes, H.; Summerville, K.; Hudson, S.; Kiakos, K.; Hartley, J. A.; Lee, M. Med. Chem. 2006, 2, 139. (c) Patil, P. C.; Lee, M. Tetrahedron Lett. 2014, 55, 3283. (d) El-Deeb, I. M.; Rose, F. J.; Healy, P. C.; von Itzstein, M. Org. Biomol. Chem. 2014, 12, 4260.

11. (a) Yanow, S. K.; Purcell, L. A.; Pradel, G.; Sato, A.; Rodriguez, A.; Lee, M.; Spithill, T. W. J. Infect. Dis. 2008, 197, 527; (b) Purcell, L. A.; Wong, K. A.; Yanow, S. K.; Lee, M.; Spithill, T. W.; Rodriguez, A. Vaccine 2008, 26, 4880.

12. (a) Good, M. F.; Reiman, J. M.; Rodriguez, I. B.; Ito, K.; Yanow, S. K.; El-Deeb, I. M.; Batzloff, M. R.; Stanisic, D. I.; Engwerda, C.; Spithill, T.; Hoffman, S. L.; Lee, M.; McPhun, V. J. Clin. Invest. 2013, 123, 3353; (b) Stanisic, D. I.; Good, M. F. Vaccine 2015, 33, 7469; (c) Good, M.; Reiman, J.; McPhun, V.; Rodriguez, B.; Ito, K.; Raja, A.; De, S.; Engwerda, C.; Lee, M.; Stanisic, D. J. Immunol. 2013, 190, 179.1. (d) Reiman, J.; McPhun, V.; Ito, K.; Lee, M.; Good, M. J. Immunol. 2013, 190, 179.2

13. (a) Black, J.; Menderes, G.; Bellone, S. et al. Mol. Cancer Ther. 2016, 15, 1900; (b) Elgersma, R. C.; Coumans, R. G.; Huijbregts. T. et al. Mol. Pharm. 2015, 12, 1813.

14. Kiakos, K.; Howard, T. T.; Lee, M.; Hartley, J. A.; McHugh, P. J. J. Biol. Chem. 2002, 277, 44576.

15. (a) Tietze, L. F.; Behrendt, F.; Pestel, G. F.; Schuberth, I.; Mitkovski, M. Chem Biodivers. 2012, 9, 2559. (b) Tietze, L. F.; Behrendt, F.; Major, F.; Krewer, B.; von Hof, J. M. Eur. J. Org. Chem. 2010, 2010, 6909. 
16. Tercel, M.; McManaway, S. P.; Liyanage, H. D.; Pruijn, F. B. ChemMedChem. 2014, 9, 2193.

17. (a) Pett, L.; Kiakos, K.; Satam, V.; Patil, P.; Laughlin-Toth, S.; Gregory, M.; Bowerman, M.;

Olson, K.; Savagian, M.; Lee, M.; Lee, M.; Wilson, W. D.; Hochhauser, D.; Hartley, J. A.

Biochim. Biophys. Acta. 2017, 1860, 617; (b) Satam, V.; Babu, B.; Patil, P.; Brien, K. A.; Olson, K.; Savagian, M.; Lee, M.; Mepham, A.; Jobe, L. B.; Bingham, J. P.; Pett, L.; Wang, S.; Ferrara, M.; Bruce, C. D.; Wilson, W. D.; Lee, M.; Hartley, J. A.; Kiakos, K. Bioorg. Med. Chem. Lett. 2015, 25, 3681; (c) Kiakos, K.; Pett, L.; Satam, V.; Patil, P.; Hochhauser, D.; Lee, M.; Hartley, J. A. Chem. Biol. 2015, 22, 862; (d) Satam, V.; Patil, P.; Babu, B.; Gregory, M.; Bowerman, M.; Savagian M, Lee M, Tzou S, Olson K, Liu Y, Ramos J, Wilson WD, Bingham JP, Kiakos K, Hartley, J. A.; Lee, M. Bioorg. Med. Chem. Lett. 2013, 23, 1699; (e) Chavda, S.; Liu, Y.; Babu, B.; Davis, R.; Sielaff, A.; Ruprich, J.; Westrate, L.; Tronrud, C.; Ferguson, A.; Franks, A.; Tzou, S.; Adkins, C.; Rice, T.; Mackay, H.; Kluza, J.; Tahir, S. A.; Lin, S.; Kiakos, K.; Bruce, C. D.; Wilson, W. D.; Hartley, J. A.; Lee, M. Biochemistry 2011, 50, 3127.

18. Patil, P.; Cousins, K.; Smith, M.; Wieskamp, S.; Ferrara, M.; Bruce, C. D.; Lee, M. Tetrahedron Lett. 2013, 54, 4756.

19. Satam, V. S.; Patil, P. C.; Babu, B.; Brien, K .A.; Gregory, M.; Bowerman M.; Sweers, J.; Mepham, A.; Lee, M. Bulg. Chem. Commun. 2016, 48, 725.

20. Synthesis of 1-(chloromethyl)-5-hydroxy-1,2 -dihydro-3- [(p-anisylbenzimidazole-2-carbonyl]$3 \mathrm{H}$-furano[2,3e]indoline, HxTfA 4: A solution of compound 7 (200 mg, $0.36 \mathrm{mmol}$ ) in THF (25 $\mathrm{mL}), \mathrm{MeOH}(5.0 \mathrm{~mL})$, and $10 \% \mathrm{Pd} / \mathrm{C}(100 \mathrm{mg})$ was hydrogenated at room temperature and atmospheric pressure for three days at room temperature. Removal of the catalyst and purification by silica gel column chromatography (7:3 ethyl acetate:hexanes) gave HxTfA 4 ( $55 \mathrm{mg}, 0.12 \mathrm{mmol}$ ) in $33 \%$ yield as a white solid. Melting point: $210-213^{\circ} \mathrm{C}(\mathrm{dec}) ; \mathrm{R}_{\mathrm{f}} 0.30$ (3:1 ethyl acetate:hexanes); IR (ATR) 3307, 2961, 2923, 2851, 1614, 1593, 1494, 1446, 1414, $1379,1334,1258,1175,1087,1015,862 \mathrm{~cm}^{-1} ;{ }^{1} \mathrm{H}$ NMR $\left(\mathrm{CD}_{3} \mathrm{OD}\right): \delta 8.07$ (d, $\left.J=8.0 \mathrm{~Hz}, 2 \mathrm{H}\right)$, $7.84(\mathrm{~s} \mathrm{br}, 1 \mathrm{H}), 7.72(\mathrm{~s} \mathrm{br}, 2 \mathrm{H}), 7.62(\mathrm{~s}, 1 \mathrm{H}), 7.50(\mathrm{~d}, J=8.0 \mathrm{~Hz}, 1 \mathrm{H}), 7.12(\mathrm{~d}, J=8.0 \mathrm{~Hz}, 2 \mathrm{H})$,

$6.86(\mathrm{~s}, 1 \mathrm{H}), 4.41(\mathrm{dd}, J=8.0 \mathrm{~Hz}, 12.0 \mathrm{~Hz}, 1 \mathrm{H}), 4.23(\mathrm{~m}, 1 \mathrm{H}), 4.04(\mathrm{~m}, 2 \mathrm{H}), 3.90(\mathrm{~s}, 3 \mathrm{H}), 3.86(\mathrm{t}$, $J=8.0 \mathrm{~Hz}, 1 \mathrm{H})$; LRMS (TOF-MS-ES $\left.{ }^{+}\right) 474\left(\mathrm{M}+\mathrm{H}^{+}, 100 \%\right) ; \mathrm{HRMS}\left(\mathrm{M}+\mathrm{H}^{+}\right)$calcd. $\mathrm{m} / \mathrm{z}$ for $\mathrm{C}_{26} \mathrm{H}_{21} \mathrm{CIN}_{3} \mathrm{O}_{4} 474.1221$, found 474.1223.

21. Chavda, S.; Babu, B.; Yanow, S. K.; Jardim, A.; Spithill, T. W.; Kiakos, K.; Kluza, J.; Hartley, J. A.; Lee, M. Bioorg. Med. Chem. 2010, 18, 5016.

22. (a) Travassos, M.; Laufer, M. K. In: UpToDate, Daily, J.; Baron E. L. (Eds), Waltham, MA (Accessed on January 8, 2017). (b) Mishra. M.; Mishra, V. K.; Kashaw, V.; Iyer A. K.; Kashaw, S. K. Eur. J. Med. Chem. 2017, 125, 1300.

\section{Legends for Figures}

Figure 1. Structure of duocarmycin SA 1; seco-CBI-TMI 2; seco-iso-CFI-TMI or tafuramycin A or TfA 3; $3 a$ is the putative active cyclopropane drug of tafuramycin $A$, and its reaction with adenine-N3; and seco-iso-CFI-Hx or HxTfA 4.

Figure 2. Synthesis of HxTfA 4. 
Figure 3. Autoradiogram of a thermal cleavage gel showing purine-N3 lesions on the bottom strand of a $5^{\prime \prime}{ }^{32} \mathrm{P}$-labeled 208-bp fragmemt of pUC18. G+A lane; 0, control; TfA 3: 0.1, 0.3, 1, 3, 10, and $30 \mu \mathrm{M}$; and HxTfA 4: 0.1, 0.3, 1, 3, 10, and $30 \mu \mathrm{M}$.

Figure 4. (A) Visualization of HxTfA 4 nuclear uptake. A549 cells were treated with the indicated concentrations of HxTfA $(0$, control; $0.5,1.0$, and $5.0 \mu \mathrm{M})$ for $24 \mathrm{~h}$, washed with PBS, and fixed with $2 \%$ paraformaldehyde (PFA). They were subsequently permeabilized and the nuclei were stained with propidium iodide (PI) before confocal microscopy imaging. The composite image presents the superimposed overlay of HxTfA fluorescence and the PI fluorescence. No HxTfA fluorescent signal was detected in the control, untreated cells under the same observation settings. (B) Fluorescence microscopy of A549 cells treated overnight with 50 and $100 \mu \mathrm{M}$ HxTfA, with the corresponding controls. Non-fixed, non-permeabilised cells were counterstained with the fluorescent MitoTracker dye $(150 \mathrm{nM})$, which selectively stains active mitochondria in live cells, and were immediately observed by microscopy. The composite image presents the superimposed HxTfA fluorescence and the Mitotracker fluorescence.

Figure 5. Effects of TfA 3 and HxTfA 4, on cellular apoptosis-related proteins and on DNA damage response. A549 cells were pre-treated with the indicated concentrations of TfA 3 and HxTfA 4 for 5 h. After $24 \mathrm{~h}$ in drug free medium, the cells were analysed by immunoblotting and confocal microscopy. (A) Results from immunoblotting experiments, detecting the levels of survivin and bcl-xL in treated and control A549 cells. (B) Immunodetection of the levels of cleaved caspase-3 and $\gamma-\mathrm{H} 2 \mathrm{AX}$ in treated and control cells. (C) Confocal microscopy images of $\gamma$ $\mathrm{H} 2 \mathrm{AX}$ foci in treated and control cells.

\section{Supporting Information}

\section{Cell Lines and Culture Conditions}

A549 cells were obtained from the European Collection of Cell Cultures and maintained in Dulbecco's Modified Eagles Medium (DMEM) containing $2 \mathrm{mM}-\mathrm{L}$ glutamine and $10 \%$ FCS. The cell lines was maintained in a humidified atmosphere at $37{ }^{\circ} \mathrm{C}$ with $5 \%$ Carbon dioxide $\left(\mathrm{CO}_{2}\right)$.

Thermal Cleavage assay was conducted on the same DNA fragment and under identical experimental conditions as in ${ }^{8 b}$.

HxTfA visualization studies. Confocal microscopy for the visualization of HxTfA, were conducted as in ${ }^{17 a, c}$ using the Zeiss 510 UV-vis microscope and the LSM510 software. Briefly, A549 cells were grown on 13-mm glass cover slips and were treated with different concentrations of 4 for $24 \mathrm{~h}$. Cells were fixed (2\% PFA), washed with PBS and then permeabilised to allow nuclear DNA staining with PI $(2 \mu \mathrm{g} / \mathrm{ml})$.

Fluorescence microscopy studies were conducted with a Leica DM R HC microscope (63x immersion oil lense), images captured by SPOT Insight 2Mp Monochrome FireWire Digital Camera and the VisiView ${ }^{\circledR}$ software. Cells were counterstained with the Mitrotracker ${ }^{\circledR}$ Red CMXRos (Thermofisher scientific) without fixation or permeabilisation. 
Immunoblotting was conducted as in ${ }^{17 a, c}$. The Bcl-xL, Survivin, and Cleaved Caspase-3 antibodies (Cell Signalling Technology) were used at a 1:1000 dilution, while the $\beta$-Actin (Cell Signalling Technology) at a 1:2000 dilution. For the detection of phosphorylated histone H2A.X (Ser139), the respective monoclonal antibody (Millipore) was used at a 1:1000 dilution.

Immunofluorescence staining for $\gamma$-H2A.X was performed as in ${ }^{17 a, c}$. Briefly, A549 cells were washed with PBS, fixed with 2\% PFA and permeabilised with PBS containing $0.5 \%$ Triton X-100. Cells were subsequently blocked in PBS 5\% BSA for $1 \mathrm{~h}$ and incubated with anti-phosphoHistone H2A.X mouse monoclonal antibody (1:100; Millipore) diluted in PBS 1\% BSA for 1h. After three washes, cells were incubated with the goat anti-mouse secondary antibody Alexa Fluor 488 (1:100; Life Technologies) for another hour. Following a further three washes in PBS $0.1 \%$ Triton X-100, nuclei were stained using a PI solution ( $2 \mu \mathrm{g} / \mathrm{ml}$; Sigma-Aldrich). $\gamma-\mathrm{H} 2 \mathrm{AX}$ levels were finally visualised using confocal microscopy. 